\title{
Correction to: Development and validation of a framework for the assessment of school curricula on the presence of evolutionary concepts (FACE)
}

\author{
Xana Sá-Pinto ${ }^{1}$, Giulia Realdon², Gregor Torkar ${ }^{3}$, Bruno Sousa ${ }^{4}$, Martha Georgiou ${ }^{5}$, Alex Jefries ${ }^{6}$, \\ Konstantinos Korfatis ${ }^{7}$, Silvia Paolucci ${ }^{8}$, Patrícia Pessoa', Joana Rocha ${ }^{9}$, Panagiotis K. Stasinakis ${ }^{10}$, \\ Bento Cavadas ${ }^{11,12}$, Angelica Crottini ${ }^{13}$, Tanja Gnidovec ${ }^{3}$, Teresa Nogueira ${ }^{14,15}$, Penelope Papadopoulou ${ }^{16}$, \\ Costanza Piccoli ${ }^{13}$, Johan Barstad ${ }^{17}$, Heloise D. Dufour ${ }^{18}$, Milena Pejchinovska ${ }^{19}$, Alma Pobric ${ }^{20}$, \\ Dragana Cvetković ${ }^{21}$ and Evangelia Mavrikaki ${ }^{2 *}$ (i)
}

\section{Correction to: Evo Edu Outreach (2021) 14:3 https://doi.org/10.1186/s12052-021-00142-2}

In this article (Sá-Pinto et al. 2021) the statement in the Funding information section was incorrectly given as "This paper is a result of a collaborative work of researchers participating in the EuroScitizen CA17127, European Funded project (Working Group 2)." and should have read "This article/publication is based upon work from COST Action EuroScitizen (CA17127; Working Group 2), supported by COST (European Cooperation in Science and Technology; www.cost.eu)."

The original article has been corrected.

\begin{abstract}
Athens, Greece. ${ }^{11}$ IPsantarém, Polytechnic Institute of Santarém-School of Education, Santarém, Portugal. ${ }^{12}$ CeiED, Lusófona University, Lisboa, Portugal. ${ }^{13} \mathrm{CIBIO} / \mathrm{InBio}$ InBIO, Universidade Do Porto, Centro de Investigação Em Biodiversidade E Recursos Genéticos, Campus Agrario de Vairão, 4485-661 Vairão, Portugal. ${ }^{14} \mathrm{INIAV}$, National Institute for Agrarian and Veterinary Research, Oeiras and Vairão, Portugal. ${ }^{15} \mathrm{CE} 3 \mathrm{c}$, Centre for Ecology, Evolution and Environmental Changes, University of Lisbon, Lisbon, Portugal. ${ }^{16}$ Department of Early Childhood Education, University of Western Macedonia, Kozani, Greece. ${ }^{17}$ University College of Green Development, Bryne, Norway. ${ }^{18}$ Le Cercle FSER, Paris, France. ${ }^{19}$ Faculty of Education, "St. Kliment Ohridski" University, Bitola, North Macedonia. ${ }^{20}$ Faculty of Science, University of Sarajevo, Sarajevo, Bosnia and Herzegovina. ${ }^{21}$ Chair of Genetics and Evolution, Faculty of Biology, University of Belgrade, Belgrade, Serbia. ${ }^{22}$ Faculty of Primary Education, National and Kapodistrian University of Athens, Navarinou 13A, 10680 Athens, Greece.
\end{abstract}

Published online: 01 December 2021

\section{Reference}

Sá-Pinto X, Realdon G, Torkar G, Sousa B, Georgiou M, Jefries A, Korfatis K, Paolucci S, Pessoa P, Rocha J, Stasinakis PK, Cavadas B, Crottini A, Gnidovec T, Nogueira T, Papadopoulou P, Piccoli C, Barstad J, Dufour HD, Pejchinovska M, Pobric A, Cvetković D, Mavrikaki E. Development and validation of a framework for the assessment of school curricula on the presence of evolutionary concepts (FACE). Evo Edu Outreach. 2021;14:3. https://doi.org/10.1186/s12052-021-00142-2.

\section{Publisher's Note}

Springer Nature remains neutral with regard to jurisdictional claims in published maps and institutional affiliations. original author(s) and the source, provide a link to the Creative Commons licence, and indicate if changes were made. The images or other third party material in this article are included in the article's Creative Commons licence, unless indicated otherwise in a credit line to the material. If material is not included in the article's Creative Commons licence and your intended use is not permitted by statutory regulation or exceeds the permitted use, you will need to obtain permission directly from the copyright holder. To view a copy of this licence, visit http://creativecommons.org/licenses/by/4.0/. The Creative Commons Public Domain Dedication waiver (http://creativeco mmons.org/publicdomain/zero/1.0/) applies to the data made available in this article, unless otherwise stated in a credit line to the data. 